\title{
Successful management of visceral disseminated varicella zoster virus infection during treatment of membranous nephropathy: a case report
}

\author{
Yoshitaka Furuto*, Mariko Kawamura, Akio Namikawa, Hiroko Takahashi and Yuko Shibuya
}

\begin{abstract}
Background: Visceral disseminated varicella zoster virus (VDVZV) infection is a rare disease with a high mortality rate (55\%) in immunocompromised patients, but it is not yet widely recognized in the field of nephrology. We report a case of VDVZV contracted during immunosuppressive therapy for membranous nephropathy.

Case presentation: A 36-year-old woman was diagnosed with membranous nephropathy and was being treated with immunosuppressive therapy consisting of $60 \mathrm{mg} /$ day prednisolone, $150 \mathrm{mg} /$ day mizoribine, and $150 \mathrm{mg} /$ day cyclosporine. Nephrosis eased; therefore, the prednisolone dosage was reduced. However, 50 days after starting immunosuppressive therapy, the patient suddenly developed strong and spontaneous abdominal pain, predominantly in the epigastric area, without muscular guarding or rebound tenderness. Blood data indicated neutrophil-dominant elevated white blood cell count, reduced platelet count, elevated transaminase and lactate dehydrogenase, slightly increased C-reactive protein, and enhanced coagulability. Abdominal computed tomography revealed a mildly increased enhancement around the root of the superior mesenteric artery with no perforation, intestinal obstruction, or thrombosis. The cause of the abdominal pain was unknown, so the patient was carefully monitored and antibiotic agents and opioid analgesics administered. The following day, blisters appeared on the patient's skin, which were diagnosed as varicella. There was a marked increase in the blood concentration of VZV-DNA; therefore, the cause of the abdominal pain was diagnosed as VDVZV. Treatment with acyclovir and immunoglobulin was immediately started, and the immunosuppressive therapy dose reduced. The abdominal pain resolved rapidly, and the patient was discharged 1 week after symptom onset.
\end{abstract}

Discussions and conclusions: This patient was VZV-lgG positive, but developed VDVZV due to reinfection. Abdominal pain due to VDVZV precedes the skin rash, which makes it difficult to diagnose before the appearance of the rash, but measuring the VZV-DNA concentration in the blood may be effective. Saving the patient's life requires urgent administration of sufficient doses of acyclovir and reduced immunosuppressive therapy.

Keywords: Varicella zoster virus, Visceral disseminated varicella zoster virus infection, Nephrotic syndrome, Membranous nephropathy, Immunosuppressive therapy

\footnotetext{
* Correspondence: furuto19761006@yahoo.co.jp

Department of Hypertension and Nephrology, NTT Medical Centre Tokyo,

5-9-22, Higasi-Gotanda, Shinagawa-ku, Tokyo 141-8625, Japan
}

(c) The Author(s). 2019 Open Access This article is distributed under the terms of the Creative Commons Attribution 4.0 International License (http://creativecommons.org/licenses/by/4.0/), which permits unrestricted use, distribution, and reproduction in any medium, provided you give appropriate credit to the original author(s) and the source, provide a link to the Creative Commons license, and indicate if changes were made. The Creative Commons Public Domain Dedication waiver (http://creativecommons.org/publicdomain/zero/1.0/) applies to the data made available in this article, unless otherwise stated. 


\section{Background}

Varicella zoster virus (VZV) infection is often experienced by patients who are in an immunocompromised state. The incidence of herpes zoster in chronic kidney disease patients is $12.4 / 1000$ people, several times higher than in healthy individuals [1]. Visceral disseminated VZV (VDVZV) infection is a rare disease with a high mortality rate that occurs in immunocompromised patients undergoing immunosuppressive therapy for blood diseases, kidney transplant recipients, patients with uncontrolled diabetes, and patients with collagen and/or kidney diseases. The symptoms are intense, beginning with sudden onset abdominal pain, and the condition tends to be serious. Early diagnosis and treatment are crucial for patient survival [2-9]. This disease is well known in the field of hematological diseases, but there is still little awareness in the field of nephrology. Recent expansion of various types of immunosuppressive therapy necessitates awareness of VDVZV infection and implementation of appropriate measures to prevent death from this disease in immunocompromised patients. Here we report the case of a patient who developed VDVZV infection approximately 50 days after starting immunosuppressive therapy (consisting of prednisolone, cyclosporine, and mizoribine) for membranous nephropathy. Her condition rapidly became serious, but with appropriate diagnosis and management we were able to save the patient.

\section{Case presentation}

\section{Case: a 36-year-old woman}

\section{Primary complaint: intense epigastric pain}

History of current condition: The patient became aware of general malaise in August, 2011. She was seen at the Department of Hypertension and Nephrology, NTT Medical Centre, Tokyo in September, and was hospitalized with nephrotic syndrome. A kidney biopsy resulted in the diagnosis of idiopathic membranous nephropathy (Stage II). Serological tests for hepatitis B and C virus were negative. Treatment with $50 \mathrm{mg} /$ day prednisolone was initiated on Day 14 of hospitalization, but the condition was refractory and so this was increased to $60 \mathrm{mg} /$ day on Day 29. Mizoribine (150 mg/day) was added to the treatment regimen on Day 28, and cyclosporine (150 mg/day) added on Day 49. Nephrosis improved thereafter, and the prednisolone dosage was reduced to $40 \mathrm{mg} /$ day. Abdominal pain developed suddenly on Day 77 , which worsened and became intense, requiring treatment with opioid analgesics on Day 79.

Medical history, family history, allergy history: nothing of note Physical findings on Day 79: height $168 \mathrm{~cm}$, weight 65.9 $\mathrm{kg}$, body mass index $23.4 \mathrm{~kg} / \mathrm{m}^{2}$, blood pressure $124 / 86$ $\mathrm{mmHg}$, heart rate $66 \mathrm{bpm}$ and regular, body temperature $37.0^{\circ} \mathrm{C}$. The patient was conscious and lucid and no nuchal rigidity, palpebral conjunctiva anemia, bulbar conjunctiva jaundice, swelling of the lymph nodes, intraoral findings, enlargement of the thyroid gland, or cardiopulmonary noise were noted. The abdomen was flat and soft with normal peristaltic sounds, strong spontaneous pain and tenderness mainly in the epigastric area, but no muscle guarding or rebound tenderness. The pain score was 10 on the Numerical Rating Scale. No costovertebral angle percussion pain. Bilateral edema was observed, but no joint pain or cutaneous findings were present. The patient was not hypertensive.

Laboratory tests on Day 79 revealed a neutrophildominant elevated white blood cell count, a slightly reduced platelet count, reduced total protein/albumin levels, elevated transaminase and lactate dehydrogenase levels, slightly increased C-reactive protein levels, hypogammaglobulinemia, and enhanced coagulability (Table 1). There was no apparent hypocomplementemia or double stranded DNA antibodies, and tests for anti-proteinase-3-anti-neutrophil cytoplasmic antibody and anti-myeloperoxidaseanti-neutrophil cytoplasmic antibodies were all negative. Urinary protein was $420 \mathrm{mg} /$ day and negative for occult blood. There were no electrocardiogram abnormalities and no notable abnormalities in the chest $x$-ray images, but niveau formation was observed on the abdominal x-ray (Fig. 1). Abdominal computed tomography (CT) (Fig. 2a) revealed a mildly increased fat tissue density around the celiac artery and root of the superior mesenteric artery, but there were no other abnormalities of note and no findings suggestive of perforation, intestinal obstruction, or thrombosis.

Clinical course: Despite pronounced abdominal pain, the vital signs were stable, there were no peritoneal irritation signs in the abdominal findings, and the tests and imaging lacked any serious findings. Cefmetazole ( $2 \mathrm{~g} /$ day) was administered as a prophylactic antibiotic, pain relief was provided with opioid analgesics, and the patient's condition was carefully monitored as the cause of pain could not be identified at this point. On the morning of Day 80, a large number of small blisters appeared on the face and trunk, which are characteristic of varicella. Skin lesion biopsy revealed that blisters had formed within the epidermis, and cells with groundglass nuclei were seen in the blister cavities (Fig. 3). Polymerase chain reaction results were positive for VZV. The blood VZV-DNA numbers had increased markedly. Initially, this patient had tested positive for VZV IgG, indicating that she had previously been infected with VZV, and the first VZV IgM test was negative on Day 80. On Day 86, paired sera samples were positive for VZV IgM. On the basis of these results (Table 2), the cause of the abdominal pain and skin lesions observed on Day 80 were confirmed to be VDVZV. The treatment course is 
Table 1 Laboratory data

\begin{tabular}{|c|c|c|c|c|c|}
\hline \multicolumn{2}{|l|}{ Urinalysis/Blood test } & \multicolumn{4}{|c|}{ Biochemistry/Immunological test/Coagulation test } \\
\hline Protein & \pm & TP & $4.7 \mathrm{~g} / \mathrm{dL}$ & $\mathrm{HbA1c}$ & $5.0 \%$ \\
\hline Occult blood & \pm & Alb & $2.2 \mathrm{~g} / \mathrm{dL}$ & TSH & $1.344 \mu \mathrm{IU} / \mathrm{mL}$ \\
\hline Red blood cell & $1-4 / \mathrm{HPF}$ & UA & $7.1 \mathrm{mg} / \mathrm{dL}$ & FT4 & $0.85 \mathrm{ng} / \mathrm{dL}$ \\
\hline Protein content & $0.42 \mathrm{~g} / \mathrm{gCr}$ & BUN & $8.6 \mathrm{mg} / \mathrm{dL}$ & $\lg G$ & $452 \mathrm{mg} / \mathrm{dL}$ \\
\hline \multicolumn{2}{|c|}{ Complete blood cell count } & $\mathrm{Cr}$ & $0.66 \mathrm{mg} / \mathrm{dL}$ & $\lg A$ & $348 \mathrm{mg} / \mathrm{dL}$ \\
\hline White blood cell & $10,600 / \mu \mathrm{L}$ & eGFR & $81 \mathrm{~mL} / \mathrm{min} / 1.73 \mathrm{~m}^{2}$ & $\lg M$ & $118 \mathrm{mg} / \mathrm{dL}$ \\
\hline Neutrophil & $9080(85.8 \%)$ & TB & $0.4 \mathrm{mg} / \mathrm{dL}$ & $\mathrm{C} 3$ & $89 \mathrm{mg} / \mathrm{dL}$ \\
\hline Lymphocyte & 1190 (11.2\%) & AST & $105 \mathrm{IU} / \mathrm{L}$ & C4 & $15.1 \mathrm{mg} / \mathrm{dL}$ \\
\hline Monocyte & $2.6 \%$ & $\mathrm{ALT}$ & $92 \mathrm{IU} / \mathrm{L}$ & $\mathrm{CH} 50$ & $32 \mathrm{U} / \mathrm{mL}$ \\
\hline Eosinophil & $0 \%$ & ALP & $142 \mathrm{IU} / \mathrm{L}$ & Antinuclear Ab & $1: 80$ \\
\hline Red blood cell & $418 \times 10^{4} / \mu \mathrm{L}$ & $\gamma$-GT & $28 \mathrm{IU} / \mathrm{L}$ & Anti-dsDNA-Ab & $(-)$ \\
\hline Hemoglobin & $13.7 \mathrm{~g} / \mathrm{dL}$ & $\mathrm{LDH}$ & $581 \mathrm{IU} / \mathrm{L}$ & Anti-Sm-Ab & $(-)$ \\
\hline Hematocrit & $39.6 \%$ & CK & $107 \mathrm{IU} / \mathrm{L}$ & Anti-MPO-ANCA & $(-)$ \\
\hline \multirow[t]{7}{*}{ Platelet } & $14.8 \times 10^{4} / \mu \mathrm{L}$ & $\mathrm{Na}$ & 139 mEq/L & Anti-PR3-ANCA & $(-)$ \\
\hline & & K & $4.0 \mathrm{mEq} / \mathrm{L}$ & PT & $121 \%$ \\
\hline & & $\mathrm{Cl}$ & 104 mEq/L & PT-INR & 0.9 \\
\hline & & $\mathrm{cCa}$ & $9.7 \mathrm{mg} / \mathrm{dL}$ & APTT & $29.7 \mathrm{~s}$ \\
\hline & & $\mathbb{I P}$ & $3.4 \mathrm{mg} / \mathrm{dL}$ & Fibrinogen & 242 mg/dl \\
\hline & & CRP & $0.4 \mathrm{mg} / \mathrm{dL}$ & FDP & $18.8 \mu \mathrm{g} / \mathrm{ml}$ \\
\hline & & Glu & 96 mg/dl & D-dimer & $11.1 \mu \mathrm{g} / \mathrm{ml}$ \\
\hline
\end{tabular}

$T P$ total protein, Alb albumin, UA uric acid, BUN blood urea nitrogen, $C r$ creatinine, eGFR estimated glomerular filtration rate, TB total bilirubin, AST aspartic aminotransferase, $A L T$ alanine aminotransferase, $A L P$ alkaline phosphatase, $\gamma$-GT $\gamma$-glutamyltransferase, $L D H$ lactate dehydrogenase, $C K$ creatine kinase, Na sodium, $K$ : potassium, $\mathrm{Cl}$ chlorine, $\mathrm{CC}$ a corrected calcium, IP inorganic phosphorus, CRP C-reactive protein, Glu glucose, HbA1c hemoglobin A1c, TSH thyroid stimulating hormone, FT4 free thyroxine, $1 g \mathrm{G}$ immunoglobulin G, IgA immunoglobulin A, lgM immunoglobulin M, Ab antibody, dsDNA double-stranded DNA, Sm Smith, MPOANCA myeloperoxidase-anti-neutrophil cytoplasmic antibody, PR3-ANCA proteinase-3-anti-neutrophil cytoplasmic antibody, PT prothrombin time, PT-INR prothrombin time-international normalized ratio, APTT activated partial thromboplastin time, FDP fibrinogen degradation products

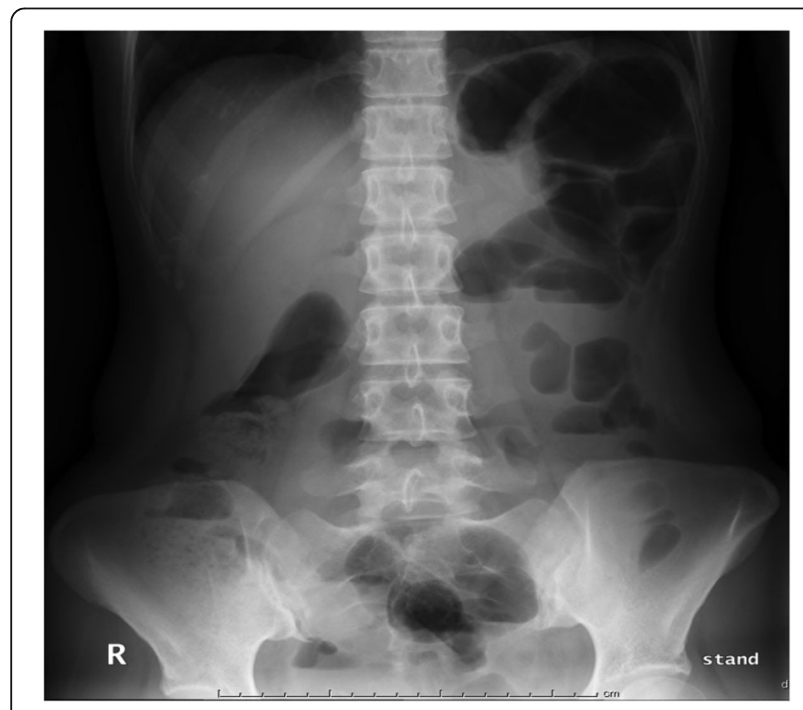

Fig. 1 Abdominal $x$-ray findings: Niveau formation shown in Fig. 4. Acyclovir (1500 mg/day) and immunoglobulin (5 g/day) were immediately administered intravenously, and the dosages of prednisolone and immunosuppressant were reduced. Liver function further worsened temporarily, disseminated intravascular coagulation was found and treatment was started. The abdominal pain quickly resolved, and the platelet count and liver function improved within 1 week of starting acyclovir. The patient was subsequently discharged. After discharge, on Day 104, we performed a repeat abdominal CT scan. This revealed mildly increased fat tissue density around the celiac artery and root of the superior mesenteric artery to reach normal levels (Fig. 2b). Retrospective evaluation of bed management revealed that another patient with herpes zoster had been in the same hospital room prior to the onset of VDVZV in this patient; therefore, it is highly likely that this was the source of the VZV infection.

\section{Discussions and conclusions}

We report the case of a patient who had previously been infected with VZV, but probably became re-infected with VZV during immunosuppressive therapy for membranous 

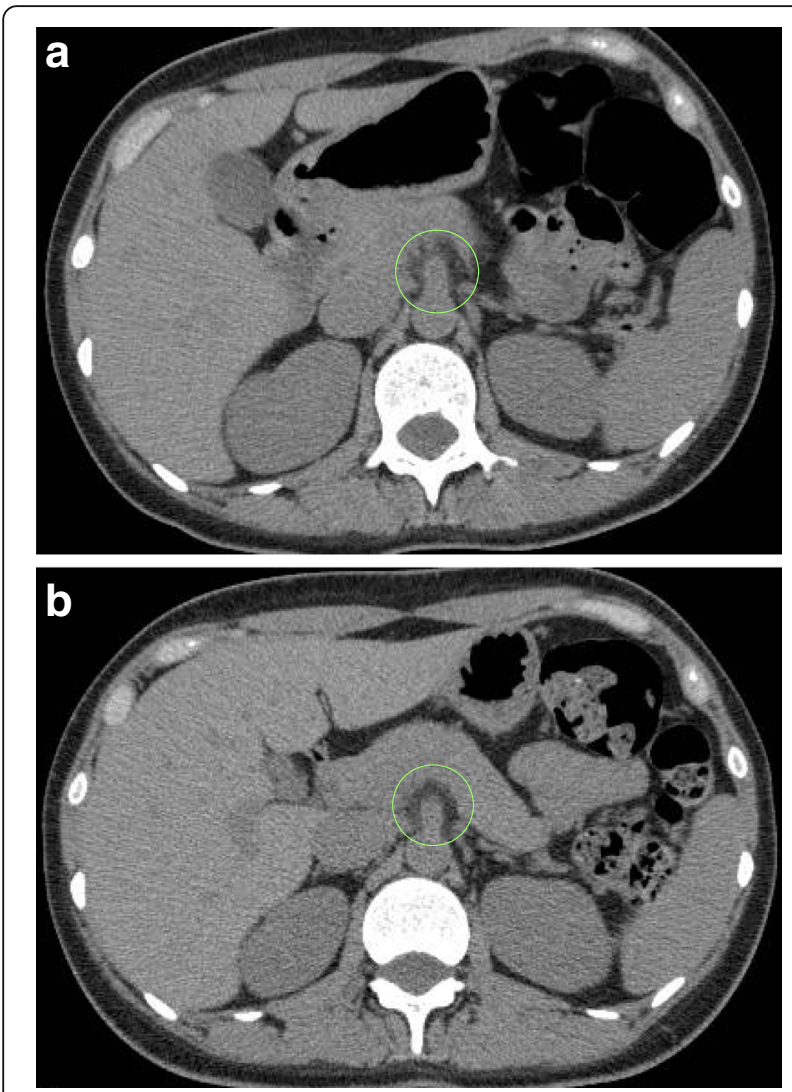

Fig. 2 a Abdominal computed tomography $(C T)$ findings on Day 79: Mild increases in $C T$ values were seen around the celiac artery and the root of the superior mesenteric artery. b Abdominal CT on Day 104: The findings compared with those of Day 79 have changed to approach normal levels

nephropathy, which led to the development of VDVZV. With careful diagnosis and management, we successfully treated the patient. It is generally considered that people with specific immunity to VZV will not become reinfected, although one study reported that four out of 62

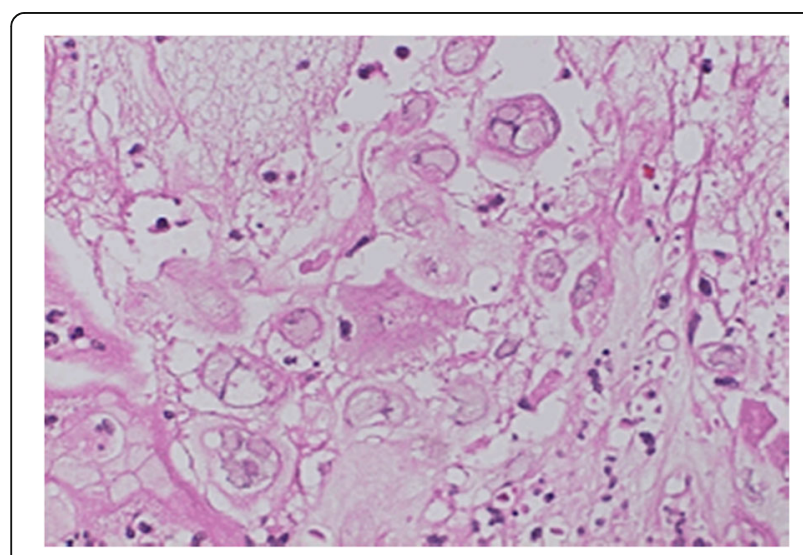

Fig. 3 Lesion skin biopsy findings: Formation of blisters in the epidermis and cells with ground-glass nuclei were observed in the blister cavities
Table $\mathbf{2} V Z V$ tests

\begin{tabular}{lll}
\hline VZV antibody titer & Day 80 & Day 86 \\
\hline VZV IgM/EIA & $0.29(-)$ & $3.43(+)$ \\
VZV IgG/EIA & $7.5(+)$ & $23.0(+)$ \\
Blood VZV DNA load & 200,000 Copy & \\
Skin biopsy VZV PCR & + & \\
\hline
\end{tabular}

EIA enzyme immunoassay, $P C R$ polymerase chain reaction, $V Z V$ varicella zoster virus

people with VZV-specific antibodies (three of whom were immunologically healthy) who came into contact with a VZV-infected person subsequently developed varicella [10]. There are also data indicating that 4.15 out of 1000 people with specific immunity are re-infected with VZV per year [11]. In immunocompromised patients, the disease type at reoccurrence is not limited to herpes zoster; VZV can also present as varicella. Steroid administration generally increases the frequency and severity of VZV infection [12], and steroid administration of 61 days or longer is a risk factor. Women are reported to have a $25 \%$ higher incidence than men [11], but the reason for this sex-related difference is unknown. Furthermore, varicella is localized to the skin in immunologically healthy people, but the lesions are not similarly limited in immunocompromised patients, who can also develop VDVZV. A report has demonstrated that relapse was an onset factor for VDVZV in three out of four cases [3]. The patient in the present study developed VDVZV despite testing positive for VZV IgG, which suggests that this was re-infection due to the presence of a patient with herpes zoster in the same hospital room prior to the onset of the condition. Therefore, we conclude that VDVZV can occur in immunocompromised patients through VZV relapse, first-time infection, or re-infection.

The symptoms of the present case were characteristic: a sub-ileus profile with intense abdominal pain but no peritoneal irritation signs or lesions (such as perforations, occlusion, or thrombosis) and extremely mild elevation of leukocytes and inflammatory response, liver dysfunction, and disseminated intravascular coagulation (DIC) test findings. The abdominal pain preceded the skin rash.

Immunocompromised patients, particularly those with underlying blood diseases or kidney transplant recipients, are susceptible to VDVZV. Gastrointestinal symptoms, including abdominal pain, intestinal obstruction, vomiting, and diarrhea, precede the skin rash by a few to 10 days $[13,14]$, and the incidence of abdominal pain is high, occurring in $82-100 \%$ of cases $[13,15]$. In a report on 15 VDVZV cases in Japan [15] (mean age was 27.9 years, 14 men and one woman), the underlying diseases were blood diseases $(n=12)$, kidney transplant $(n=2)$, and kidney disease $(n=1)$, and 13 of the patients 


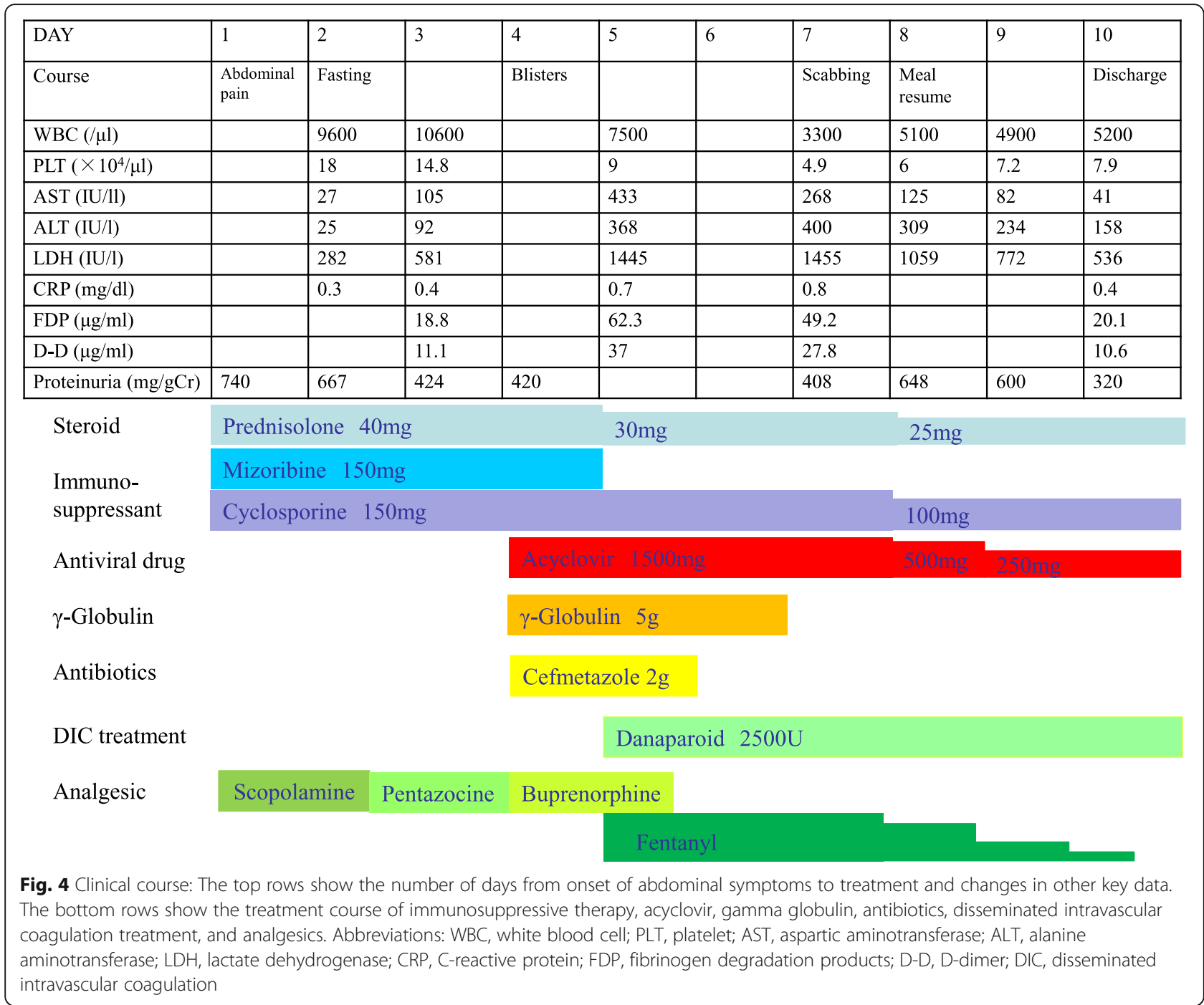

were using steroids and/or immunosuppressants. The initial symptom was abdominal pain in 14 patients and back pain in one patient, and CT findings were almost completely normal. However, increased CT values of abdominal perivascular adipose tissue were observed in one case, erosion was evident by endoscopy in some cases, and some cases presented with a rash. The mean time from initial symptoms to appearance of the rash was 4.6 days. Narcotics were used for analgesia in five patients, and diagnostic methods included identification of the rash and anti-VZV IgM/IgG, serum VZV-DNA, serum VZV antigens, PCR from lesion site, and Tzanck tests. The mean time from initial symptoms to starting treatment was 4.5 days; all patients were treated with acyclovir and four patients were also treated with gamma globulin. The outcome was reported as death in four cases, and it was reported that the mean time from initial symptoms to starting treatment was 4.2 days for the 11 patients who survived, while a mean time of 5.5 days was reported for those who died. These results reiterate the importance of prompt treatment. In the present case, it was 3 days from the onset of abdominal pain to the appearance of the rash, diagnosis of VDVZV, and initiation of treatment. Until the rash appears, VDVZV is often diagnosed as abdominal pain of unknown etiology. It has been reported that the blood VZV-DNA concentration for herpes zoster is, on average, 1710 copies compared with an average of 214,214 copies for VDVZV. This disparity could be used as a method for diagnosis during the time before the appearance of the rash [16], and measuring blood VZV-DNA numbers when VDVZV is suspected could be useful. The imaging findings are usually nonspecific; increased lipid concentration around the superior mesenteric artery by $\mathrm{CT}$ has been reported [17], and the present case had similar CT findings (Fig. 1).

Since VZV is known to be associated with vasculitis and giant cell arteritis, it is possible that the clinical findings relate to the arteritis accompanying VZV infection $[18,19]$. 
In the context of autoimmunity or immunodeficiency, VZV vasculitis often occurs in the cerebral blood vessels; [20] however, it can occur in the abdominal blood vessel, as was observed in the present case.

There have been reports of upper gastrointestinal bleeding or herpes-like lesions on the mucosal or serosal side of the gastrointestinal tract [21, 22]. Pain management is difficult in such cases and may require opioid analgesics, but there are also reports where even large doses of opioids were not sufficient $[14,17]$. There is a theory that the abdominal pain is caused by proliferation of the VZV on the celiac and mesenteric ganglia [23], but there are number of different theories $[13,21]$ and the details are still unknown. This study had some limitations. Specifically, we did not perform gastroscopy and intestinal endoscopy, and no viral genotyping was available to allow differentiation of disseminated zoster (reactivation) from re-infection.

The prognosis of VDVZV is poor; often becoming much more serious with complications of DIC, encephalitis, pneumonia, and intestinal necrosis; and the mortality rate is reported to be extremely high, at approximately 55\% [24]. Recently, the incidence of VDVZV in Japanese patients receiving allogenic hematopoietic stem cell transplantation was reported to be $0.8 \%$, and the mortality rate was 20\% [4]. Delayed diagnosis has fatal outcomes, sometimes within a few days $[2,23]$. Therefore, awareness of this condition as a severe infection is vital.

Infection prevention is important and measures must be taken to ensure that immunocompromised patients do not come into contact with VZV. In the USA, a live attenuated vaccine is recommended to prevent herpes zoster and postherpetic neuralgia in general patients aged 60 years and older, and there is also a recombinant vaccine recommended for individuals 50 years and older [25-27]. Administration of live vaccines is normally contraindicated as a prophylactic measure for immunocompromised patients, but their use after organ transplant has been reported [28]. However, pediatricians do not consider the administration of live vaccines to be absolutely contraindicated for transplant recipients, and there are reports that such patients may develop a fever and rash, but do not subsequently develop VZV infection even after exposure to the virus $[29,30]$. Therefore, there is no consensus of opinion.

Prophylactic oral administration of acyclovir has been reported to inhibit VZV activation in hematopoietic stem cell transplantation cases [31, 32], but the inhibitory effect has been demonstrated to cease once administration is stopped [33]. Acyclovir is excreted via the kidneys; therefore, ongoing prophylactic administration requires caution in patients with renal insufficiency. The KDIGO guidelines recommend intravenous injection of VZV immunoglobulin or immunoglobulin within $96 \mathrm{~h}$ as a preventative measure to counteract exposure of kidney transplant recipients to VZV [34]. The same guidelines advocate a combination of intravenous administration of acyclovir and temporary reduction of immunosuppressants as a treatment for VZV [34]. A report of the VZVrelated death of a patient during immunosuppressive therapy for kidney disease treatment has been published; however, the acyclovir dose was too low $(250 \mathrm{mg} /$ day $)$ and the steroid dose was not reduced [2]. Awareness of VDVZV must be reiterated not only for patients with blood diseases and kidney transplant recipients, but also for patients with kidney disease undergoing immunosuppressive therapy. It is important to start treatment with a sufficient dose of acyclovir as soon as possible and to reduce the dose of immunosuppressive therapy.

\section{Abbreviation}

VDVZV: Visceral disseminated varicella zoster virus

Acknowledgements

We thank Editage (http://www.editage.jp) for English language editing.

\section{Author's contributions}

YF was responsible for conceptualization, data curation, formal analysis, funding acquisition, investigation, methodology, project administration, resources, software, validation, visualization, writing - original draft and writing - review \& editing the manuscript. YF, MK, AN, HT and YS supervised the data. All authors read and approved the final manuscript.

Funding

None.

\section{Availability of data and materials}

Not applicable.

\section{Ethics approval and consent to participate}

The procedures and possible risks associated with this study were explained and written informed consent for participation obtained according to the policy of the Ethical Review Board of NTT Medical Centre Tokyo.

\section{Consent for publication}

Written informed consent was obtained from the patient for the publication of this case report.

\section{Competing interests}

The authors declare that they have no competing interests.

Received: 7 March 2019 Accepted: 14 June 2019

Published online: 15 July 2019

\section{References}

1. Wu MY, Hsu YH, Su CL, Lin YF, Lin HW. Risk of herpes zoster in CKD: a matched-cohort study based on administrative data. Am J Kidney Dis. 2012; 60:548-52.

2. Habuka M, Wada Y, Kurosawa Y, Yamamoto S, Tani Y, Ohashi R, et al. Fatal visceral disseminated varicella zoster infection during initial remission induction therapy in a patient with lupus nephritis and rheumatoid arthritis - possible association with mycophenolate mofetil and high-dose glucocorticoid therapy: a case report. BMC Res Notes. 2018;11:165.

3. Fehr T, Bossart W, Wahl C, Binswanger U. Disseminated Varicella infection in adult renal allograft recipients: four cases and a review of the literature. Transplantation. 2002;73:608-11.

4. Doki N, Miyawaki S, Tanaka M, Kudo D, Wake A, Oshima K, et al. Visceral varicella zoster infection after allogeneic stem cell transplantation. Transpl Infect Dis. 2013;15:314-8.

5. Malkud S, Patil SM. Disseminated cutaneous herpes zoster in a patient with uncontrolled diabetes mellitus. J Clin Diagn Res. 2015;9:WD01-2. 
6. Shin $\mathrm{BS}, \mathrm{Na} \mathrm{CH}$, Song IG, Choi KC. A case of human immunodeficiency virus infection initially presented with disseminated herpes zoster. Ann Dermatol. 2010;22:199-202

7. Tsuji H, Yoshifuji H, Fujii T, Matsuo T, Nakashima R, Imura Y, et al. Visceral disseminated varicella zoster virus infection after rituzimab treatment for granulomatosis with polyangitis. Mod Rheumatol. 2017;27:155-61.

8. Rommelaere M, Marechal C, Yombi JC, Goffin E, Kanaan N. Disseminated varicella zoster virus infection in adult renal transplant recipients:outcome and risk factors. Transplant Proc. 2012;44:2814-7.

9. Loftus MJ, Yong MK, Wilson S, Peleg AY. Fatal disseminated visceral varicella zoster virus infection in a renal transplant recipient. Transpl Infect Dis. 2019 Feb 12:e13062. https://doi.org/10.1111/tid.13062 Epub ahead of print.

10. Gershon AA, Steinberg SP, Gelb L. Clinical reinfection with varicella zoster virus. J Infect Dis. 1984;149:137-42.

11. Toyama N, Shiraki K. Society of the Miyazaki Prefecture Dermatologists. Epidemiology of herpes zoster and its relationship to varicella in Japan: A 10-year survey of 48,388 herpes zoster cases in Miyazaki prefecture. J Med Virol. 2009;81:2053-8.

12. Hyvernat H, Roger PM, Pereira C, Saint-Paul MC, Vandenbos F, Bernardin G. Fatal Varicella hepatitis in an asthmatic adult after short-term corticosteroid treatment. Eur J Intern Med. 2005;16:361-2.

13. David DS, Tegtmier BR, O'Donnel MR, Paz IB, McCarty TM. Visceral varicellazoster after bone marrow transplantation: report of a case series and review of the literature. Am J Gastroenterol. 1998;93:810-3.

14. Hyland JM, Butterworth J. Severe acute visceral pain from varicella zoster virus. Anesth Analg. 2003;97:1117-8.

15. Rowland P, Wald ER, Mirro JR, Yunis E, Albo VC, Wollman MR, et al. Progressive varicella presenting with pain and minimal skin involvement in children with acute lymphoblastic leukemia. J Clin Oncol. 1995;13:1697-703.

16. Kronenberg A, Bossart W, Wuthrich RP, Cao C, Lautenschlager S, Wiegand ND, et al. Retrospective analysis of varicella zoster virus (VZV) copy DNA numbers in plasma of immunocompetent patents with herpes zoster, of immunocompromised patient with disseminated VZV disease, and of asymptomatic solid organ transplant recipients. Transpl Infect Dis. 2005;7:116-21.

17. Yamada S, Iwasaki T, Satoh A, Tsuboi Y, Yanagi M, Takahashi T, et al. A case of visceral varicella-zoster virus infection after autologous peripheral blood stem cell transplantation in which severe abdominal pain preceded the skin rash. Nihon Shokakibyo Gakkai Zasshi. 2010;107:1947-55.

18. Gershon AA, Gershon M. Varicella Zoster virus and giant cell arteritis. J Infect Dis. 2016;213(12):1859-61.

19. Gilden D, White T, Boyer PJ, Galetta KM, Hedley-Whyte ET, Frank M, et al. Varicella Zoster virus infection in granulomatous arteritis of the aorta. J Infect Dis. 2016;213(12):1866-71.

20. Gilden D, Cohrs RJ, Mahalinqam R, Nagel MA. Varicella Zoster virus vasculopathies: diverse clinical manifestations, laboratory features, pathogenesis, and treatment. Lancet Neurol. 2009;8:731-40.

21. Yagi T, Karasuno T, Hasegawa T, Yasumi M, Kawamoto S, Murakami M, et al. Acute abdomen without cutaneous signs of varicella zoster virus infection as a late complication of allogeneic bone marrow transplantation: importance of empiric therapy with acyclovir. Bone Marrow Transplant. 2000;25:1003.

22. Takatoku M, Muroi K, Kawano-Yamamoto C, Nagai T, Komatsu N, Ozawa K. Involvement of the esophagus and stomach as a first manifestation of varicella zoster virus infection after allogeneic bone marrow transplantation. Intern Med. 2004;43:861-4.

23. Au WY, Ma SY, Cheng VCC, Ooi CGC, Lie AKW. Disseminated zoster, hyponatraemia, severe abdominal pain and leukaemia relapse: recognition of a new clinical quartet after bone marrow transplantation. Br J Dermatol. 2003;149:862-5.

24. Schiller GJ, Nimer SD, Gajewski JL, Golde DW. Abdominal presentation of varicella-zoster infection in recipients of allogeneic bone marrow transplantation. Bone Marrow Transplant. 1991;7:489-91.

25. Oxman MN, Levin MJ, Johnson GR, Schmader KE, Straus SE, Gelb LD, et al. A vaccine to prevent herpes zoster and postherpetic neuralgia in older adults. N Engl J Med. 2005;352:2271-84.

26. Harpaz R, Ortega-Sanchez IR, Seward JF. Prevention of herpes zoster: recommendations of the Advisory Committee on Immunization Practices (ACIP). MMWR Recomm Rep. 2008;57:1-30 quiz CE32-34.

27. Dooling KL, Guo A, Patel M, Lee GM, Moore K, Belongia EA, et al. Recommendations of the Advisory Committee on Immunization Practices for Use of Herpes Zoster Vaccines. MMWR Morb Mortal Wkly Rep. 2018; 67(3):103-8.
28. Shinjoh M, Miyairi I, Hoshino K, Takahashi T, Nakayama T. Effective and safe immunizations with live-attenuated vaccines for children after living donor liver transplantation. Vaccine. 2008;26:6859-63.

29. Sester M, Gartner BC, Girndt M, Sester U. Vaccination of the solid organ transplant recipient. Transplantation Review. 2008;22:274-84.

30. Masters JM, Thomsen AK, Hayney MS. Vaccinations in solid-organ transplant patients: what a health professional should know. J Am Pharm Assoc. 2009; 49:458-9.

31. Kanda Y, Mineishi S, Saito T, Saito A, Yamada S, Ohnishi M, et al. Long-term low-dose acyclovir against varicella-zoster virus reactivation after allogenic hematopoietic stem cell transplantation. Bone Marrow Transplant. 2001;28: 689-92.

32. Asano-Mori Y, Kanda Y, Oshima K, Kako S, Shinohara A, Nakasone H, et al. Long-term ultra-low dose acyclovir against varicella-zoster virus reactivation after allogeneic stem cell transplantation. Am J Hematol. 2008;83:472-6.

33. Thomson KJ, Hart DP, Banerjee L, Ward KN, Peggs KS, Mackinnon S. The effect of low-dose acyclovir on reactivation of varicella zoster virus after allogeneic haemopoietic stem cell transplantation. Bone Marrow Transplant. 2005:35:1065.

34. Kasiske BL, Zeier MG, Craig JC, Ekberg H, Garvey CA, Green MD, et al. KDIGO clinical practice guideline for the care of kidney transplant recipients. Am J Transplant. 2009;9:S41-52.

\section{Publisher's Note}

Springer Nature remains neutral with regard to jurisdictional claims in published maps and institutional affiliations.

\section{Ready to submit your research? Choose BMC and benefit from:}

- fast, convenient online submission

- thorough peer review by experienced researchers in your field

- rapid publication on acceptance

- support for research data, including large and complex data types

- gold Open Access which fosters wider collaboration and increased citations

- maximum visibility for your research: over $100 \mathrm{M}$ website views per year

At BMC, research is always in progress.

Learn more biomedcentral.com/submissions 